\title{
Selective recovery of chromium, copper, nickel, and zinc from an acid solution using an environmentally friendly process
}

\author{
Manuela D. Machado • Eduardo V. Soares • \\ Helena M. V. M. Soares
}

\begin{abstract}
Purpose Real electroplating effluents contain multiple metals. An important point related with the feasibility of the bioremediation process is linked with the strategy to recover selectively metals. In this work, a multimetal solution, obtained after microwave acid digestion of the ashes resulted from the incineration of Saccharomyces cerevisiae contaminated biomass, was used to recover selectively chromium, copper, nickel, and zinc.

Results The acid solution contained 3.8, 0.4, 2.8, and $0.2 \mathrm{~g} / \mathrm{L}$ of chromium(III), copper, nickel, and zinc, respectively. The strategy developed consisted of recovering copper (97.6\%), as a metal, by electrolyzing the solution at a controlled potential. Then, the simultaneous alkalinization of the solution $\left(\mathrm{pH}\right.$ 14), addition of $\mathrm{H}_{2} \mathrm{O}_{2}$, and heating of the solution led to a complete oxidation of chromium and nickel recovery $(87.9 \%$ as a precipitate of nickel hydroxide). After adjusting the $\mathrm{pH}$ of the remaining
\end{abstract}

solution at $\mathrm{pH} 10$, selective recovery of zinc $(82.7 \%$ as zinc hydroxide) and chromium $(95.4 \%$ as a solution of cromate) was achieved.

Conclusion The approach, used in the present work, allowed a selective and efficient recovery of chromium, copper, nickel, and zinc from an acid solution using a combined electrochemical and chemical process. The strategy proposed can be used for the selective recovery of metals present in an acid digestion solution, which resulted from the incineration of ashes of biomass used in the treatment of heavy metals rich industrial effluents.

Keywords Chemical precipitation $\cdot$ Electrolysis $\cdot$ Heavy metals $\cdot$ Recycling $\cdot$ Selective recovery $\cdot$ Chemical speciation

\section{Introduction}

Electroplating effluents often contain excessive concentrations of metals such as chromium, copper, nickel, and zinc that must be removed before being discharged. The environmental threat caused by heavy metals, linked with the lack of efficiency or feasibility of conventional physicochemical technologies, has promoted a big effort research, particularly in the last years, on the development of alternative processes for effective and low cost treatment of metal-bearing industrial effluents (Gadd 2009).

Cells of Saccharomyces cerevisiae seem to be a promissory type of biomass for the bioremediation of wastewaters containing heavy metals, as they have the ability of removing a wide variety of metals from synthetic (Chen and Wang 2008; Machado et al. 2008; Machado et al. 2010a; Ruta et al. 2010; Zouboulis et al. 2001) and real effluents (Machado et al. 2010a, b, c; Parvathi and Nagendran 2007; Stoll and Duncan 1997). It was shown 
that flocculent brewing strains of $S$. cerevisiae seem particularly appropriated as they have a higher metal uptake than nonflocculent strains (Soares et al. 2002). On the other hand, heat-killed biomass (at $45^{\circ} \mathrm{C}$ ) of brewing yeast cells present higher metal removal than live cells (Machado et al. 2009) and retain their flocculation properties, which overcome the problem of cell separation process after effluent treatment (Machado et al. 2008). In addition, it was demonstrated that flocculent brewing yeast cells are able to treat efficiently complex industrial effluents loaded with several heavy metals (Machado et al. 2010a, b, c).

After heavy metals have been removed by yeast cells from industrial effluents, heavy metal recovery from biomass allows metal recycling since the metals can be reintroduced in the industrial process or resailed. The efficiency of metal recovery is largely dependent on the concentration of metals present in the solution after being extracted from the biomass. Desorption of heavy metals from yeast cells has been attempted by several authors using different eluants such as mineral and organic acids or complexing agents (Ferraz et al. 2004; Strandberg et al. 1981; Wilhelmi and Duncan 1996); however, the lower capacity to concentrate metals strongly limits the feasibility of the recovery process. Alternatively, the amount of yeast biomass loaded with heavy metals (coming from the bioremediation process) can be strongly reduced by incineration; then, the acid digestion of the ashes generates a concentrated metal and acid solution (Machado et al. 2010d).

Usually, industrial effluents contain multiple heavy metals. An important point related to the metals recovery is linked with the strategy to remove selectively metals from the solution. The simultaneous recovery of several heavy metals is indubitably a more ambitious and difficult challenge. Thus, it is not surprising that a limited work has been devoted to this objective. The selective recovery of copper, nickel, and zinc by sequential precipitation using sulfides was described (Tokuda et al. 2008). However, sulfide toxicity and consequently the safety aspects related with its handling strongly impair its practical application (Huisman et al. 2006).

Recently, our group developed a new strategy for recycling selectively heavy metals from yeast cells contaminated with copper, nickel, and zinc, coming from the treatment of real electroplating effluents (Machado et al. 2010d). However, real electroplating effluents can be even more complex and present simultaneously chromium, copper, nickel, and zinc (Machado et al. 2010b). The difficulty of the selective recovery of these four metals is well illustrated in a recent work published by Kuchar et al. (2010). In this paper, the sulfidation was conducted to a selective recovery of $\mathrm{Cu}$ and $\mathrm{Zn}(96.6 \%$ and $91.5 \%$, respectively); however, only $64.3 \%$ and $30 \%$ of $\mathrm{Ni}$ and $\mathrm{Cr}$, respectively, were selectively recovered.

In the present work, a multistage process, which combines electrochemical and chemical methods, was developed for recovering selective and efficiently chromium, copper, nickel, and zinc from an acid solution. The acid solution resulted from the incineration of contaminated brewing cells of $S$. cerevisiae loaded with heavy metals. It is important to point out that the challenge presented in this work is more ambitious and difficult than the other one previously carried out (Machado et al. 2010d) since it implies the selective recovery of four metals; one of them [chromium(III)] requires a completely different strategy. With the strategy developed in this work, chromium, copper, nickel, and zinc were selectively recovered with high yield ( $\geq 83 \%$ for all four metals). As far as we know, this is the first work, which reports the recovery of these four metals with high selectivity.

\section{Materials and methods}

\subsection{Incineration of yeast cells and acid digestion of ashes}

Brewing cells of $S$. cerevisiae, used in the bioremediation of an electroplating effluent, were dried at $45^{\circ} \mathrm{C}$ and then incinerated at $550^{\circ} \mathrm{C}$, in a muffle furnace (Nabertherm, L5/ C6), until constant weight. Then, the ashes were acid digested with hydrochloric acid $1 \mathrm{~mol} / \mathrm{L}$ (prepared from proanalysis acid, Merck) as previously described (Machado et al. 2010d).

After the digestion of the ashes, total chromium, copper, nickel, and zinc concentrations were determined in the acid solution by atomic absorption spectroscopy with flame atomization (AAS-FA) in a Perkin Elmer AAnalyst 400 spectrometer (Norwalk, CT, USA) in order to control the efficiency of the digestion.

This experiment was performed in duplicate.

\subsection{Copper recovery by electrolysis}

Copper recovery was performed in a batch reactor, as previously described (Machado et al. 2010d). Briefly, an electrochemical cell, constituted by a platinum net as cathode, a platinum wire as anode and an electrode of $\mathrm{Ag}$ / $\mathrm{AgCl}(\mathrm{KCl} 3 \mathrm{~mol} / \mathrm{L})$ as reference electrode, was immersed in $40 \mathrm{~mL}$ of the acid digestion solution containing chromium(III), copper, nickel, and zinc, previously adjusted at $\mathrm{pH}$ 2. Then, a constant cathodic potential of $-0.6 \mathrm{~V}$ was applied at $40^{\circ} \mathrm{C}$ with a constant agitation of $500 \mathrm{rpm}$. During copper electrodeposition, electric current intensity varied between 0.1 and $0.01 \mathrm{~A}$.

In order to determine the efficiency of metal recovery, copper concentration was quantified in the remained acid solution by AAS-FA. For controlling the selective recovery of copper, total chromium, nickel, and zinc were quantified in the metallic copper, by AAS-FA, after redissolving it in nitric acid. 
All experiments and determinations were done at least in duplicate.

\subsection{Computer chemical simulations}

Chemical speciation calculations were carried out using the MINEQL+ software (version 4.5; Schecher and McAvoy 2003). Metal speciation analysis with MINEQL+ generates chemical equilibrium concentrations of all species being considered in the model by the program reactions, based on component stability constants and molar concentrations. Computational simulations were performed considering the total heavy metal (chromium, nickel, and zinc quantified in the remained acid digested solution after copper deposition) concentrations and the solubility product constants (Martell and Smith 2004).

2.4 Nickel recovery by simultaneous alkalinization at $\mathrm{pH} 14$ and oxidation of chromium(III) to chromium(VI)

Since the final $\mathrm{pH}$ was very high ( $\mathrm{pH} 14)$, the mass of sodium hydroxide necessary to adjust the $\mathrm{pH}$ was theoretically calculated taken into account the amount of hydroxide necessary to raise the $\mathrm{pH}$ from 2 to 14 plus the amount of hydroxide necessary to convert chromium, nickel, and zinc to chromate $\left[\mathrm{CrO}_{4}{ }^{2-}(\mathrm{aq})\right]$, nickel hydroxide $\left[\mathrm{Ni}(\mathrm{OH})_{2}\right.$ (s)], and tetrahydroxozincate(II) $\left[\mathrm{Zn}(\mathrm{OH})_{4}{ }^{2-}(\mathrm{aq})\right]$, respectively; due to the high ionic strength of the solution, calculation of $\mathrm{pH}$ was performed considering the $\mathrm{OH}^{-}$ activity instead of $\mathrm{OH}^{-}$concentration. Then, small pellets of solid sodium hydroxide were added. After all sodium hydroxide was dissolved, an excess of hydrogen peroxide [five times more the amount of chromium(III)] was added. Finally, the suspension was boiled during $15 \mathrm{~min}$, in order to decompose the excess of hydrogen peroxide, and centrifuged at $2,800 \mathrm{~g}$ for $10 \mathrm{~min}$, for recovering the precipitate of nickel hydroxide, $\mathrm{Ni}(\mathrm{OH})_{2}(\mathrm{~s})$. Nickel hydroxide was firstly washed two times with $10 \mathrm{~mL}$ of $\mathrm{NaOH}$ at $\mathrm{pH}$ 14, followed by four washing steps with $10 \mathrm{~mL}$ of $\mathrm{NaOH}$ at $\mathrm{pH} 10$; the precipitate was recovered by centrifugation at $2,800 \mathrm{~g}$ during $10 \mathrm{~min}$.

Oxidation of chromium(III) to chromium(VI) was controlled by determining the amount of total chromium and chromium(VI) in the remained supernatant solution. Total chromium and chromium(VI) were quantified by AAS-FA and the diphenylcarbazide method according to the standard methods (APHA et al. 1998), respectively.

For characterization of nickel hydroxide and determination of nickel recovery, concentrations of total chromium, copper, nickel, sodium, and zinc were measured in solution after appropriate dissolution in $\mathrm{HNO}_{3} 20 \%(v / v)$ and dilution of a dried (at $105^{\circ} \mathrm{C}$ until constant weight) weighted amount of nickel hydroxide. Total chromium, copper, nickel, and zinc were measured by AAS-FA. Sodium concentration was determined by emission atomic spectroscopy (EAS) in a Perkin Elmer AAnalyst 400 spectrometer (Norwalk, CT, USA). The amount of chlorides present in the precipitate was calculated as the difference between the total amount of a dried (at $105^{\circ} \mathrm{C}$ until constant weight) precipitate weighted gravimetrically and the sum of copper, nickel, zinc (all in the form of metal hydroxide), and sodium quantified in the precipitate.

All experiments and determinations were done at least in duplicate.

\subsection{Zinc and chromium recovery by adjustment of $\mathrm{pH}$ at 10}

After nickel recovery, the remained supernatant solution, containing chromium(VI) and zinc, was adjusted at $\mathrm{pH} 10$ by addition of $\mathrm{HCl} 37 \%$ followed by centrifugation at $2,800 \mathrm{~g}$ for $10 \mathrm{~min}$. Zinc was recovered as a precipitate of zinc hydroxide, $\mathrm{Zn}(\mathrm{OH})_{2(\mathrm{~s})}$, and chromium remained in solution as chromate, $\mathrm{CrO}_{4}{ }^{2-}$ (aq) .

The amount of zinc recovered was determined by AAS-FA, after appropriate dissolution of part of the dried (at $105^{\circ} \mathrm{C}$ until constant weight) precipitate in $\mathrm{HNO}_{3} 20 \%(v / v)$ and dilution.

For characterization of chromate solution and quantification of chromium recovery, total chromium, copper, nickel, sodium, and zinc were determined in the remained supernatant solution as it was described above. Chlorides were analyzed according to the standard methods (APHA et al. 1998) by the argentometric method. All experiments and determinations were done at least in duplicate.

\section{Results and discussion}

Brewing flocculent cells of $S$. cerevisiae were used to treat a real electroplating effluent containing chromium, copper, nickel, and zinc (Machado et al. 2010b). This biomass, loaded with heavy metals, was incinerated and subsequently acid digested under the conditions previously optimized (Machado et al. 2010d). The acid solution contained 3.8, $0.4,2.8$, and $0.2 \mathrm{~g} / \mathrm{L}$ of chromium(III), copper, nickel, and zinc, respectively. This solution was used to develop a nearly closed cycle for recovering selectively chromium, copper, nickel, and zinc (Fig. 1). This work is a more ambitious and difficult challenge than the other one previously carried out (Machado et al. 2010d) since it implies the selective recovery of four metals; one of them [chromium (III)] requires a completely different strategy. If the methodology developed by us in the previous paper (Machado et al. 2010d) has been applied to the present case [an acid solution containing chromium(III), copper, nickel, and zinc], only the selective recovery of copper, by electrolysis, and of zinc, as a soluble complex of tetrahydroxozincate after the subsequent 
alkalinization of the solution up to $\mathrm{pH} 14$, would have been attained; nickel and chromium(III) would remain both precipitated, as nickel hydroxide and chromium(III) hydroxide (Fig. 2), respectively.

In the present work, copper was, firstly, electrolysed from the multimetal acid solution after previous $\mathrm{pH}$ adjustment of the acid digested solution at $\mathrm{pH} 2$. After $1 \mathrm{~h}$ of electrolysis, a residual concentration of copper, $9 \mathrm{mg} / \mathrm{L}$, remained in the acid solution. This corresponded to a recovery of $97.6 \%$ of copper (Fig. 1), which is in agreement with our previous results (Machado et al. 2010d) and the results from other authors. Suzuki et al. (1995) reported the complete removal of copper from a mixture of copper, nickel, and zinc by electrolysis at a controlled potential. In the same way, Aydin et al. (1998) reported the electrodeposition of $99.3 \%$ of copper from a solution containing bismuth, cadmium, cobalt, copper, nickel, and zinc. In the present work, the purity of the metal recovered was $99.8 \%$ (Fig. 1), containing minor amounts of chromium, nickel, and zinc (Table 1). Doulakas et al. (2000) had reported a similar copper purity (higher than 99.5\%) when copper was recovered from a multielement solution containing cadmium, copper, lead, and zinc ions, at a controlled potential. The high purity of the final product

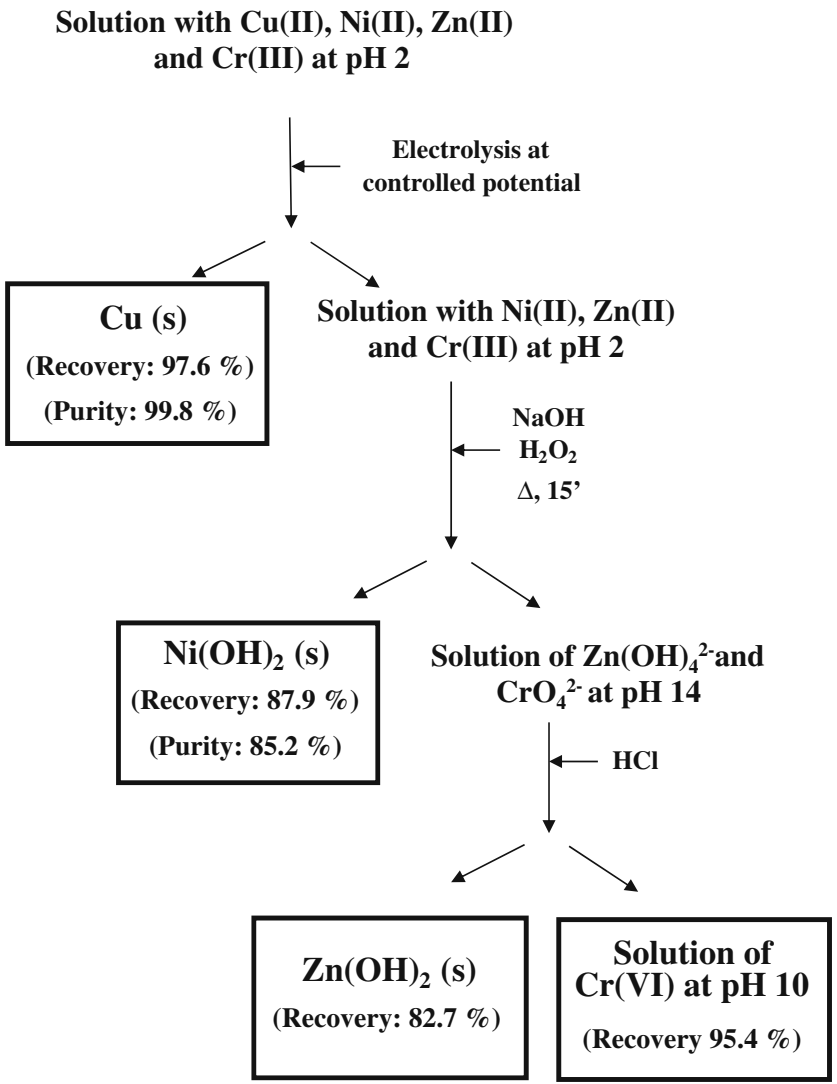

Fig. 1 Diagrammatic representation of the overall environmentally friendly process proposed in the present work. The process allows an efficient and selective recovery of chromium, copper, nickel, and zinc from an acid solution
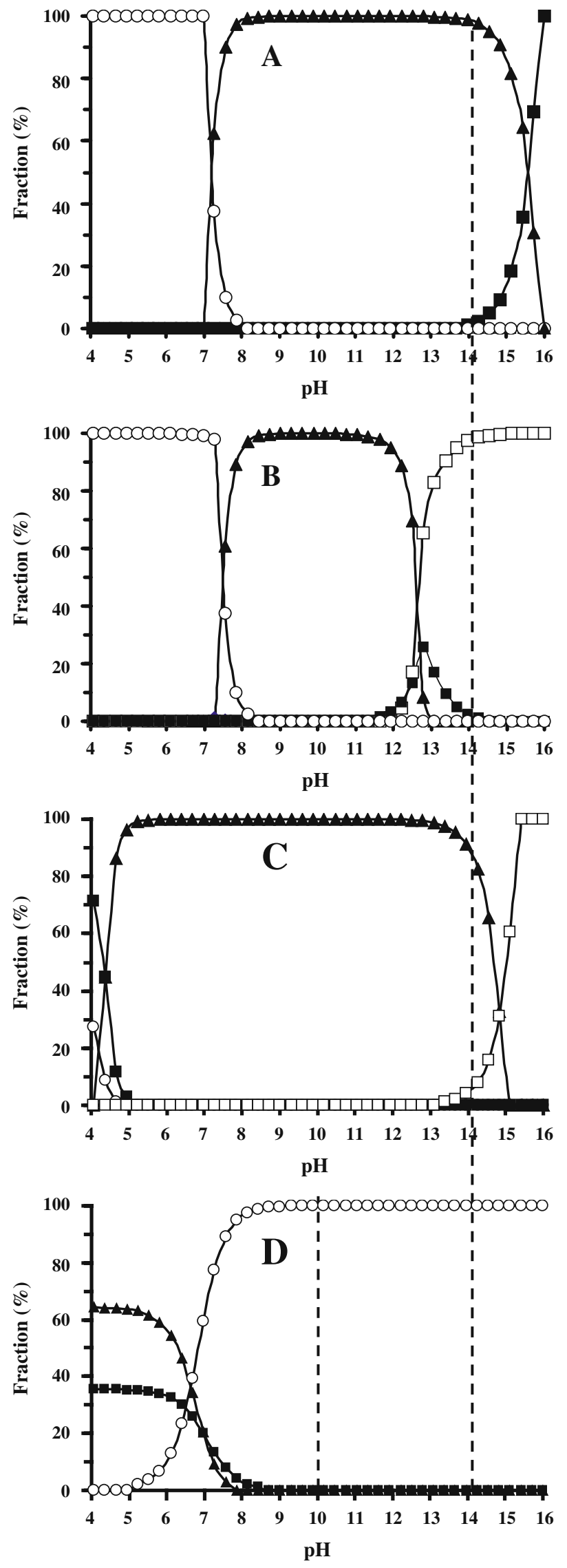
Fig. 2 Species distribution diagram of $2.8 \mathrm{~g} / \mathrm{L}$ of nickel (a), $0.2 \mathrm{~g} / \mathrm{L}$ of zinc (b), and $3.8 \mathrm{~g} / \mathrm{L}$ of chromium(III) (c) or chromium(VI) (d), at different $\mathrm{pH}$ values. The different species of metals in solution were calculated with a chemical equilibrium computer program (MINEQL+) and assuming the total concentrations of metals remained in the acid digested solution after copper electrolysis. Nickel or zinc species: free metal ion, $\mathrm{M}_{(\mathrm{aq})}{ }^{2+}$ (empty circle), $\mathrm{M}(\mathrm{OH})_{2(\mathrm{~s})}$ (filled triangle). $\mathrm{M}(\mathrm{OH})_{3}{ }^{-}{ }_{(\mathrm{aq})}$ (filled square) and $\mathrm{M}(\mathrm{OH})_{4}{ }^{2-}{ }_{(\mathrm{aq})}$ (empty square). Chromium(III) species: $\mathrm{Cr}_{(\mathrm{aq})}{ }^{3+}$ (empty circle), $\mathrm{Cr}(\mathrm{OH})_{(\mathrm{aq})}{ }^{2+}$ (filled square), $\mathrm{Cr}(\mathrm{OH})_{3(\mathrm{~s})}$ (filled triangle), and $\mathrm{Cr}(\mathrm{OH})_{4}^{-}$(aq) (empty square). Chromium(VI) species: $\mathrm{CrO}_{4}{ }^{2-}{ }_{\text {(aq) }}$ (empty circle), $\mathrm{Cr}_{2} \mathrm{O}_{7}{ }^{2-}{ }_{\text {(aq) }}$ (filled triangle), and $\mathrm{HCrO}_{4}^{-}$(aq) (filled square)

obtained allows its introduction in the market. On the other hand, it can also be introduced in several types of copper plating baths (namely in sulfate copper acid baths and fluoborate acid baths as well as in copper pyrophosphateplating baths and brass plating solutions; Homer 1994).

Then, the possibility of recovering selectively chromium, nickel, and zinc by chemical precipitation was evaluated. For this purpose, chemical speciation distribution diagrams, using the MINEQL+ program, were drawn assuming the concentrations of chromium, nickel, and zinc present in the remained acid solution (Fig. 2). The analysis of figure pointed out that at $\mathrm{pH} 6$, chromium(III) should be totally precipitated, as $\mathrm{Cr}(\mathrm{OH})_{3}(\mathrm{~s})$ (Fig. 2c), whereas nickel (Fig. 2a) and zinc (Fig. 2b) should remain soluble, as free metal ions, in solution. From a theoretical point of view, these results suggested that chromium(III) could be selectively recovered by adjusting the $\mathrm{pH}$ of the solution obtained after electrolysis at $\mathrm{pH}$ 6; nickel and zinc ions should remain in solution. However, experimental studies evidenced that part of nickel and zinc coprecipitated with chromium(III) hydroxide (data not shown), which unabled this strategy. On the other hand, the analysis of Fig. 2a, c evidenced that whatever the $\mathrm{pH}$ at which the solution was adjusted, at least two metals would be remained in the same phase (precipitated or soluble).

From these results, we definitively concluded that a new strategy should be developed to recover selectively the three metals. The analysis of the chemical speciation distribution diagram of chromium(VI) (Fig. 2d), together with the chemical speciation distribution diagrams for nickel (Fig. 2a) and zinc (Fig. 2b), pointed out that nickel could be selectively recovered, as a precipitate of nickel hydroxide, from the remaining solution [chromium and zinc will remain totally soluble as anions of chromate, $\mathrm{CrO}_{4}{ }^{2}$ (aq), and tetrahydroxozincate, $\mathrm{Zn}(\mathrm{OH})_{4}{ }^{2-}(\mathrm{aq})$, respectively] at $\mathrm{pH} 14$. In a recent paper published by Kuchar et al. (2010), only $64.3 \%$ of nickel and $30 \%$ of chromium were selectively recovered from a plating sludge, containing chromium(III), copper, nickel, and zinc, after previous oxidation of chromium(III) to chromium(VI) at $\mathrm{pH} 10$; in this paper (Kuchar et al. 2010), less than $60 \%$ of the total amount of chromium(III) was oxidized to chromium(VI). However, it is described in the literature (Vogel 1987) that oxidation of chromium(III) to chromium(VI) can be easily promoted using an excess of hydrogen peroxide, under alkaline conditions, according to the equation below:

$2\left[\mathrm{Cr}(\mathrm{OH})_{4}\right]_{(\mathrm{aq})}^{-}+3 \mathrm{H}_{2} \mathrm{O}_{2(\mathrm{aq})}+2 \mathrm{OH}_{(\mathrm{aq})}^{-} \rightarrow 2 \mathrm{CrO}_{4}^{2-}{ }_{(\mathrm{aq})}^{2-}+8 \mathrm{H}_{2} \mathrm{O}_{(\mathrm{l})}$

The analysis of the chemical speciation distribution diagram of chromium(III) (Fig. 2c) evidences that at $\mathrm{pH} 14$, about $5 \%$ of chromium(III) is solubilized as tetrahydroxochromate(III), $\left[\mathrm{Cr}(\mathrm{OH})_{4}\right]_{(\mathrm{aq})}{ }^{-}$. All these facts allowed us to design another strategy to recover selectively chromium and zinc. This strategy was based on the oxidation of chromium(III) to chromium(VI) under stronger alkaline conditions. Thus, we decided to increase the $\mathrm{pH}$ of the suspension up to 14 and add an excess of hydrogen peroxide (Fig. 1). Under these conditions, 95.4\% of chromium(III) was rapidly (15 min were used) oxidized to chromium(VI), and $87.9 \%$ of nickel was recovered, as nickel hydroxide, with a purity of $85.2 \%$ (Fig. 1). Chromium and chlorides were the main contaminants present in the nickel hydroxide (Table 1). Minor amounts of copper, sodium, and zinc were also detected. The nickel hydroxide, obtained under the present conditions, can be reused to adjust nickel concentration in the Watts baths, which present a concentration of $30-60 \mathrm{~g} / \mathrm{L}$ of $\mathrm{NiCl}_{2} \cdot 6 \mathrm{H}_{2} \mathrm{O}$ (Homer 1994). If a high purified final product is required, the recovered nickel hydroxide can be washed using $\mathrm{NaOH}$ at $\mathrm{pH} 10$ in a similar way as it was done in a previous work (Machado et al. 2010d).

After nickel recovery, the remained solution was mainly constituted by high amounts of chromium(VI) and small amounts of zinc. Chemical speciation distribution diagrams of zinc (Fig. 2b) and chromium(VI) (Fig. 2d) predicted that, at $\mathrm{pH} 10$, zinc should be totally precipitated, as $\mathrm{Zn}(\mathrm{OH})_{2}(\mathrm{~s})$, and chromium(VI) will remain in the supernatant, as $\mathrm{CrO}_{4}{ }^{2-}$ (aq).
Table 1 Main impurities presented in metallic copper, nickel hydroxide, and chromate solution

\begin{tabular}{lllllll}
\hline Metals & \multicolumn{5}{l}{ Contaminants $(\%, w / w)$} & \\
\cline { 2 - 7 } & $\mathrm{Na}$ & $\mathrm{C} 1$ & $\mathrm{Cu}$ & $\mathrm{Ni}$ & $\mathrm{Zn}$ & $\mathrm{Cr}$ \\
\hline $\mathrm{Cu}(\mathrm{s})$ & - & - & - & 0.050 & 0.060 & 0.070 \\
$\mathrm{Ni}(\mathrm{OH})_{2}(\mathrm{~s})$ & 0.30 & 11.4 & 0.40 & - & 0.40 & 2.3 \\
$\mathrm{CrO}_{4}{ }^{2-}(\mathrm{aq})$ & 5.78 & 18.2 & $\leq 3.0 \times 10^{-5}$ & $\leq 3.0 \times 10^{-5}$ & $\leq 4.0 \times 10^{-5}$ & - \\
\hline
\end{tabular}


So, the $\mathrm{pH}$ of the remained solution was adjusted to $\mathrm{pH} 10$ with concentrated hydrochloric acid. After this procedure, $82.7 \%$ of the zinc initially present in the solution was recovered (Fig. 1). Since the initial solution only contained $0.2 \mathrm{~g} / \mathrm{L}$ of zinc, the final amount of zinc hydroxide recovered was very low. So, no attempts to purify this amount of zinc hydroxide were performed; in this case, the recovered zinc hydroxide should be reintroduced in a subsequent initial acid digested solution. On the other hand, if significant amounts of zinc are present in the initial acid solution, large amounts of zinc hydroxide will be recovered. In this case, if a high purified final product is required, the recovered zinc hydroxide can be washed using $\mathrm{NaOH}$ at $\mathrm{pH} 10$ in a similar way as it was done previously (Machado et al. 2010d).

The concentration of chromium present in the recovered cromate solution was $2.6 \mathrm{~g} / \mathrm{L}$, which corresponded to a recovery of $95.4 \%$ (Fig. 1). This solution contained chlorides and sodium ions, as major contaminants, and vestigial amounts of copper, nickel, and zinc (Table 1). This solution can be reused in the preparation of chromium plating solution of conventional $\left(150-400 \mathrm{~g} / \mathrm{L}\right.$ of $\left.\mathrm{CrO}_{3}\right)$ and cocatalyzed baths (150-400 g/L of $\mathrm{CrO}_{3}$; Homer 1994).

A preliminary economic study was carried out to estimate the economic feasibility of the flowsheet proposed. Estimation of the cost was based on the following economic factors: (1) the energy consumption (and the cost) for copper electrodeposition; (2) the cost associated to the amount of sodium hydroxide consumed to increase the $\mathrm{pH}$ of the acid solution to 14; (3) the cost associated to the use of the hydrogen peroxide to oxidize chromium(III) to chromium(VI); and (4) the cost to decrease the $\mathrm{pH}$ of solution to 10 . The preliminary cost analysis of the process, considering $1 \mathrm{~m}^{3}$ of acid solution, is presented in Table 2 . The prices of the end products were compared with the market prices of equivalent products. Unless copper, which can be recovered at a low cost, the other metals are recovered with a higher price than if they are purchased in the market. Since $\mathrm{KOH}(0.30 \mathrm{US} \$ / \mathrm{kg})$ is cheaper than
$\mathrm{NaOH}$ (0.50 US\$/kg; Chang 2011), the replacement of $\mathrm{NaOH}$ by KOH will reduce the total cost associated with the selective recovery of the metals from $\sim 290$ to $\sim 228$ US $\$$. Considering the use of $\mathrm{KOH}$, the preliminary economic study pointed out that the end products are prepared with a cost of about two times higher than the market prices of equivalent products.

\section{Conclusions}

In this work, a new and multistep process for recovering selectively chromium, copper, nickel, and zinc, with high yield, from an acid solution was developed. For this purpose, a solution obtained after microwave acid (hydrochloric acid was used) digestion of the ashes produced from the incineration of contaminated biomass used to treat electroplating effluents, was used. The acid solution contained 3.8, 0.4, 2.8, and $0.2 \mathrm{~g} / \mathrm{L}$ of chromium(III), copper, nickel, and zinc, respectively.

The developed process comprised three steps: (1) selective recovery of copper, as metallic copper, by electrolysis at controlled potential; (2) selective recovery of nickel, as nickel hydroxide, by simultaneous alkalinization at $\mathrm{pH} 14$ and oxidation of chromium(III) to chromium (VI) of the previous solution; (3) selective recovery of zinc, as zinc hydroxide, and of chromium(VI), as a solution of cromate, by adjusting the $\mathrm{pH}$ of the previous solution at $\mathrm{pH} 10$. With this process, final recoveries of $95.4 \%, 97.6 \%$, $87.9 \%$, and $82.7 \%$ of chromium(VI), copper, nickel, and zinc, respectively, were obtained. The purity of the metals recovered allows reintroducing them in the electroplating process.

The process developed in the present work, at laboratory scale, seems to be a promissory approach to be applied in the selective recovery of metals present in an acid digestion solution resulted from the incineration of ashes of biomass used in the treatment of effluents containing four heavy
Table 2 Preliminary cost analysis of the selective recovery of chromium (VI), copper, nickel, and zinc from an acid solution $\left(1 \mathrm{~m}^{3}\right)$

\footnotetext{
${ }^{\mathrm{a}}$ International Chemical Information Service (Chang 2011)

${ }^{\mathrm{b}}$ Local market as a salt

${ }^{\mathrm{c}}$ London Metal Exchange (2011)
}

\begin{tabular}{lllll}
\hline Item & Unit & Quantity & US\$/unit & Cost \\
\hline Energy for copper recovery & $\mathrm{kWh}$ & 5.2 & 0.1 & 0.52 \\
Amount of $\mathrm{NaOH}^{\mathrm{a}}$ & $\mathrm{kg}$ & 310 & 0.5 & 155 \\
Amount of $\mathrm{H}_{2} \mathrm{O}_{2}(50 \%)^{\mathrm{a}}$ & $\mathrm{kg}$ & 38.7 & 0.8 & 31 \\
Amount of $\mathrm{HCl}(33 \%)^{\mathrm{a}}$ & $\mathrm{kg}$ & 738.8 & 0.14 & 103.43 \\
Total cost & & & & 289.95 \\
Products & $\mathrm{kg}$ & 3.6 & 9.8 & 35.3 \\
Chromium & & 0.39 & 9.6 & 3.74 \\
Copper & $\mathrm{kg}$ & 2.5 & 30 & 75 \\
Nickel $^{\mathrm{b}}$ & $\mathrm{kg}$ & 0.17 & 7.3 & 1.24 \\
Zinc $^{\mathrm{b}}$ & $\mathrm{kg}$ & & & 115.28 \\
Total cost for products & & & & \\
\hline
\end{tabular}


metals. Although the price of the recovered metals is, globally, higher than if they are purchased from the market, the strategy proposed is environmentally friendly and can contribute to avoid the world mineral reserve exhaustion.

Acknowledgments The authors thank to the Fundação para a Ciência e a Tecnologia (FCT) from Portuguese Government for the financial support of this work with FEDER founds, by the Project POCTI/CTA/47875/2002. Manuela D. Machado is also gratefully acknowledged for a grant scholarship financed under the same project and the grant from FCT (SFRH/BD/31755/2006).

The authors also wish to thank Doctor Rui Boaventura from the Faculty of Engineering of Porto University for the use of analytical facilities (microwave digestor). We would also like to thank to one of the reviewers for his/her valuable comments.

\section{References}

APHA, AWWA, WPCF, (1998) Standard methods for the examination of water and wastewater. American Public Health Association, Washington, D.C

Aydin F, Yavuz O, Ziyadanogullari B, Ziyadanogullari R (1998) Recovery of copper, cobalt, nickel, cadmium, zinc and bismuth from electrolytic copper solution. Turk J Chem 22(2):149-154

Chang J (2011) Indicative chemical prices. International Chemical Information Service. http://www.icis.com/staticpages/a-e.htm. Accessed 07 February 2011

Chen C, Wang JL (2008) Removal of $\mathrm{Pb}^{2+}, \mathrm{Ag}^{+}, \mathrm{Cs}^{+}$and $\mathrm{Sr}^{2+}$ from aqueous solution by brewery's waste biomass. J Hazard Mat 151 (1):65-70

Doulakas L, Novy K, Stucki CC (2000) Recovery of Cu, Pb, Cd and $\mathrm{Zn}$ from synthetic mixture by selective electrodeposition in chloride solution. Electrochim Acta 46(2-3):349-356

Ferraz AI, Tavares T, Teixeira JA (2004) Cr(III) removal and recovery from Saccharomyces cerevisiae. Chem Eng J 105:11-20

Gadd GM (2009) Biosorption: critical review of scientific rationale, environmental importance and significance for pollution treatment. J Chem Technol Biotechnol 84(1):13-28

Homer H (1994) Electroplating. In: Othmer K (ed) Encyclopedia of chemical technology, vol 9. Wiley, New York, pp 807-810

Huisman JL, Schouten G, Schultz C (2006) Biologically produced sulphide for purification of process streams, effluent treatment and recovery of metals in the metal and mining industry. Hydrometallurgy 83(1-4):106-113

Kuchar D, Fukuta T, Kubota M, Matsuda H (2010) Recovery of Cu, $\mathrm{Zn}, \mathrm{Ni}$ and $\mathrm{Cr}$ from plating sludge by combined sulfidation and oxidation treatment. Int J Environ Sci Eng 2(2):62-66

London Metal Exchange (2011) Non-ferrous metal. http://www.lme. com/non-ferrous/index.asp. Accessed 07 February 2011

Machado MD, Santos MSF, Gouveia C, Soares HMVM, Soares EV (2008) Removal of heavy metals using a brewer's yeast strain of Saccharomyces cerevisiae: the flocculation as a separation process. Bioresour Technol 99(7):2107-2115

Machado MD, Janssens S, Soares HMVM, Soares EV (2009) Removal of heavy metals using a brewer's yeast strain of Saccharomyces cerevisiae: advantages of using dead biomass. J Appl Microbiol 106(6):1792-1804
Machado MD, Soares EV, Soares HMVM (2010a) Removal of heavy metals using a brewer's yeast strain of Saccharomyces cerevisiae: chemical speciation as a tool in the prediction and improving of treatment efficiency of real electroplating effluents. J Hazard Mat 180(1-3):347-353

Machado MD, Soares EV, Soares HMVM (2010b) Removal of heavy metals using a brewer's yeast strain of Saccharomyces cerevisiae: application to the treatment of real electroplating effluents containing multielements. J Chem Technol Biot 85(10):13531360

Machado MD, Soares HMVM, Soares EV (2010c) Removal of chromium, copper and nickel from an electroplating effluent using a flocculent brewer's yeast strain of Saccharomyces cerevisiae. Water Air Soil Poll 212:199-204

Machado MD, Soares EV, Soares HMVM (2010d) Selective recovery of copper, nickel and zinc from ashes produced from Saccharomyces cerevisiae contaminated biomass used in the treatment of real electroplating effluents. J Hazard Mat 184:357-363

Martell AE, Smith RM (2004) NIST Standard Reference Database 46 Version 8.0, NIST Critically Selected Stability Constants of Metal Complexes Database, US Department of Commerce, National Institute of Standards and Technology

Parvathi K, Nagendran R (2007) Biosorption of chromium from effluent generated in chrome-electroplating unit using Saccharomyces cerevisiae. Sep Sci Technol 42(3):625-638

Ruta L, Paraschivescu C, Matache M, Avramescu S, Farcasanu IC (2010) Removing heavy metals from synthetic effluents using "kamikaze" Saccharomyces cerevisiae cells. Appl Microbiol Biotechnol 85(3):763-771

Schecher WD, McAvoy DC (2003) MINEQL+: a chemical equilibrium modeling system, Version 4.5 for Windows, User's Manual, Environmental Research Software, Hallowell, Maine

Soares EV, De Coninck G, Duarte F, Soares HMVM (2002) Use of Saccharomyces cerevisiae for $\mathrm{Cu}^{2+}$ removal from solution: the advantages of using a flocculent strain. Biotechnol Lett 24:663666

Stoll A, Duncan JR (1997) Implementation of a continuous-flow stirred bioreactor system in the bioremediation of heavy metals from industrial waste water. Environ Pollut 97(3):247-251

Strandberg GW, Shumate PE II, Parrot JR (1981) Microbial cells as biosorbents for heavy metals: accumulation of uranium by Saccharomyces cerevisiae and Pseudomonas aeruginosa. Appl Environ Microbiol 41:237-245

Suzuki R, Li WH, Schwartz M, Nobe K (1995) Segmented porouselectrode flow reactors for the electrochemical treatment of commingled metal plating wastes. Plat Surf Finish 82(12):5865

Tokuda H, Kuchar D, Mihara N, Kubota M, Marsuda H, Fukuta T (2008) Study on reaction kinetics and selective precipitation of $\mathrm{Cu}, \mathrm{Zn}, \mathrm{Ni}$ and $\mathrm{Sn}$ with $\mathrm{H}_{2} \mathrm{~S}$ in single-metal and multi-metal systems. Chemosphere 73(9):1448-1452

Vogel AI (1987) Vogel's qualitative inorganic analysis, 6th edn. Longman Scientific and Technical, Harlow, England, p 112

Wilhelmi BS, Duncan JR (1996) Reusability of immobilised Saccharomyces cerevisiae with successive copper adsorption-desorption cycles. Biotechnol Lett 18(5):531-536

Zouboulis AI, Matis KA, Lazaridis NK (2001) Removal of metal ions from simulated wastewater by Saccharomyces yeast biomass: combining biosorption and flotation processes. Sep Sci Technol 36(3):349-365 